\title{
In vivo evaluation of the mutagenic potential and phytochemical characterization of oleoresin from Copaifera duckei Dwyer
}

\author{
Edson Luis Maistro ${ }^{1}$, José Carlos Tavares Carvalho ${ }^{1}$, Vera Cascon $^{2}$ and Maria Auxiliadora Coelho Kaplan ${ }^{2}$ \\ ${ }^{1}$ Universidade José do Rosário Vellano, Faculdade de Farmácia, Alfenas, MG, Brazil. \\ ${ }^{2}$ Universidade Federal do Rio de Janeiro, Núcleo de Pesquisas de Produtos Naturais, Rio de Janeiro, RJ, \\ Brazil.
}

\begin{abstract}
We characterized the chemical constituents of Copaifera duckei oleoresin and used dermal application to Wistar rats to evaluated its possible mutagenic and cytotoxic activities on peripheral blood reticulocytes and bone marrow cells. Chemical characterization of the oleoresin revealed the presence of sesquiterpene hydrocarbons, an unidentified neutral diterpene and diterpene acids. To evaluate mutagenicity evaluation the rats were treated with 10,25 and $50 \%$ of the $L_{50}$ dose of the oleoresin for three consecutive days and peripheral blood collected after $0,24,48$ and $72 \mathrm{~h}$ for micronucleus analysis. The rats were humanly sacrificed 24 hours after the last treatment and chromosome preparations made using standard techniques. At the three concentrations and the three time intervals tested we found that there were no statistically significant differences in either the mean number of micronucleated reticulocytes (MNRETs) or the number of chromosomal aberrations as to the negative control. However, at 25 and $50 \%$ of the $L_{50}$ dose of the oleoresin there was a significant decrease in the mitotic index (MI) as compared to the negative control. Under our experimental conditions, $C$. duckei V11 oleoresin produced no mutagenic effects on bone marrow cells or in peripheral reticulocytes as assessed by chromosome aberrations and the micronucleus test respectively, but showed cytotoxic activity at high doses.
\end{abstract}

Key words: Copaifera duckei (Caesalpinaceae), phytochemical characterization, micronucleus test, chromosome aberrations, cytotoxic effect.

Received: November 23, 2004; Accepted: March 24, 2005.

\section{Introduction}

The oleoresin obtained by tapping the trunk of trees of the genus Copaifera (Caesalpinaceae), is widely used in Brazilian popular medicine under the name 'óleo de copaíba' (copaiba oleoresin), predominantly as a healing, antiseptic and anti-inflammatory agent (Le Cointe, 1934; Pio Corrêa, 1984).

Copaiba oleoresins have been used as unique vegetal drugs despite the existence of more than 20 species of Copaifera in Brazil (Dwyer, 1951) and the significant inter and intra species differences in chemical composition (Cascon and Gilbert, 2000) copaiba oleoresins have been used medicinally throughout Brazil. The oleoresin is a natural solution of diterpene acids in an essential oil composed mainly of sesquiterpenes and has been reported as being bactericidal (Maruzzela and Sicurella, 1960; Opdyke, 1976; Cascon et al., 2000; Tincusi et al., 2002), anti-

Send correspondence to Edson Luis Maistro. Universidade José do Rosário Vellano, Laboratório de Genética, Caixa Postal 23, 37130-000 Alfenas, MG, Brazil. E-mail: edson.maistro@ unifenas.br. helminthic (Pellegrino, 1967; Gilbert et al., 1972), analgesic (Fernandes and Pereira, 1989), anti-inflammatory (Basile et al., 1988; Fernandes et al., 1992; Veiga-Junior et al., 2001) and gastro-protective (Paiva et al., 1998) as well as showing antitumor (Ohsaki et al., 1994; Lima et al., 1998) and trypanocidal (Cascon et al., 1998) activity. However, in several of these evaluations commercial copaiba oleoresins were used, the chemical composition of which was either not given or only partially described.

There exists considerable interest in determining the risks that plant extracts may pose to health, since many of these extracts contain compounds known to cause diseases or even death to animals and humans by acting as natural mutagens and carcinogens (Panigrahi and Rao, 1982; Araújo et al., 1999; Burim et al., 1999; Chacon et al., 2002). The objective of the study described in this paper was to characterize the chemical constituents of Copaifera duckei oleoresin and evaluate its mutagenic and cytotoxic potential by applying the micronucleus test to peripheral blood and analyzing chromosomal aberrations in bone marrow cells of Wistar rats treated with this oleoresin. 


\section{Material and Methods}

\section{Plant material and chemical analysis}

We collected 4.4 litres of Copaifera duckei Dwyer (V11) oleoresin from trees growing at a site in Mazagão county in the Brazilian state of Amapá near the town of Macapá at $00^{\circ} 02^{\prime} 56^{\prime \prime} \mathrm{N} ; 051^{\circ} 44^{\prime} 46^{\prime \prime} \mathrm{W}$ on the 7 of December 1996. The collection of oleoresin and botanical material was made by Vera Cascon and Jonas de Oliveira Cardoso with the collaboration of the Amapá Institute of Scientific and Technological research (Instituto de Pesquisas Científicas e Tecnológicas do Estado do Amapá, IEPA). Botanical identification was made by Antônio Sérgio Lima da Silva, Museu Paraense Emílio Goeldi (MG), Belém, Pará, Brazil. The botanical material collection number was 031 deposited at 12/02/1998.

An equal volume of dichloromethane was added to the crude oleoresin which was esterified with diazomethane in ether and analyzed using gas chromatography - mass spectrometry (GC-MS) in a Hewlett Packard HP 6890 chromatograph (column $30 \mathrm{~m}$ x $250 \mu \mathrm{m}$ x 0,25 $\mu \mathrm{m}$ ) - HP 5 mass spectrometer $(70 \mathrm{eV}$, mass selective detector $5972 \mathrm{~A})$, using PFK as a reference. The temperature was started at $70{ }^{\circ} \mathrm{C}$, rising by $2{ }^{\circ} \mathrm{C}$ per minute to $300{ }^{\circ} \mathrm{C}$.

Both sesquiterpenes and methyl esters of diterpene acids were analyzed in the same sample and the majority of the compounds were characterized using the Wiley Library/ Mass Spectra 275 and by comparison of retention times with data published by Braga (1994).

\section{Animals and assay procedures}

Experiments were carried out using six-week-old Wistar rats (Rattus norvegicus) weighing 90-110 g acquired from Alfenas University animal house and kept in polyethylene boxes $(n=6)$ in a climate-controlled environment $\left(25 \pm 4{ }^{\circ} \mathrm{C}, 55 \pm 5 \%\right.$ humidity $)$ with a $12 \mathrm{~h}$ light/dark cycle $(07: 00 \mathrm{~h}$ to $19: 00 \mathrm{~h})$ and fed Labina-Purina (Agribrands Purina do Brasil Ltda, Paulínia, São Paulo, Brazil) and water ad libitum. The rats were divided into three experimental and two control groups each containing three females $\left(\mathrm{F}_{1}\right.$ to $\left.\mathrm{F}_{3}\right)$ and three males $\left(\mathrm{M}_{1}\right.$ to $\left.\mathrm{M}_{3}\right)$. Rats in the experimental groups received $10 \%, 25 \%$ or $50 \%$ of the $\mathrm{LD}_{50}$ dose $(7.467 \mathrm{mg} / \mathrm{kg}$ body weight, Carvalho and Cascon, 2003) of Copaifera duckei oleoresin by dorsal dermal injection for 3 consecutive days at $24 \mathrm{~h}$ intervals. The negative control group received $0.9 \%(\mathrm{w} / \mathrm{v}) \mathrm{NaCl}$ by the same route as the experimental rats and the positive control group $30 \mathrm{mg}$ of cyclophosphamide/ kg body weight.

For the micronucleus test blood smears were collected using peripheral tail blood from experimental and control rats, the blood being collected before the first injection $(0 \mathrm{~h})$ and at 24,48 and $72 \mathrm{~h}$ after the first injection (Hayashi et al., 1990). A total of 8000 reticulocytes were analyzed per rat, 2000 for each collection time. All rats were humanly sacrificed $72 \mathrm{~h}$ after the first injection, each rat being injected intraperitoneally with $0.5 \mathrm{~mL}$ of $0.16 \%$ $(\mathrm{w} / \mathrm{v})$ aqueous colchicine $90 \mathrm{~min}$ prior to euthanasia. Bone marrow was obtained at autopsy $(\mathrm{t}=72 \mathrm{~h})$ for the analysis of chromosome aberrations in metaphase cells using the method of Ford and Hamerton (1956). The UNIFENAS Animal Bioethical Committee approved the present study on $17^{\text {th }}$ August 2003.

To detect micronuclei and chromosome aberrations slides were Giemsa stained and 100 metaphases per animal analyzed to determine the mean number of chromosomal aberrations in a blind test. Chromosomal aberrations were classified according to Savage (1976) as gaps, breaks, deletions, fragments, rings and dicentric chromosomes. Gaps were recorded but not included in the statistical analysis. The mitotic index was obtained by counting the number of mitotic cells in 1000 cells per animal. The data were submitted to one-way analysis of variance (ANOVA) and the Tukey-Kramer multiple comparison test using the GraphPad Instat ${ }^{\circledR}$ software version 3.01 (GraphPad Software, Inc., San Diego, USA). Results were considered statistically significant at $\mathrm{p}<0.05$.

\section{Results}

\section{Phytochemical characterization}

The analysis of the proportional distribution of terpenes in the oleoresin showed the presence of $7.2 \%$ of sesquiterpene hydrocarbons, $1.8 \%$ of an unidentified neutral diterpene and $92.2 \%$ of diterpene acids (Figure 1). The main components of the oleoresin are the sesquiterpenes trans- $\beta$-caryophyllene $(4.5 \%)$, trans- $\alpha$-bergamotene $(1.0 \%), \alpha$-humulene $(0.7 \%)$, and $\beta$-bisabolene $(1.0 \%)$ and the diterpene copalic (3.7\%), polyalthic $(27.1 \%)$ and hardwickiic (59.3\%) acids.

\section{Mutagenic and cytotoxic evaluation}

The results obtained in the in vivo test system are presented in Tables 1 and 2. The micronuclei assay showed no

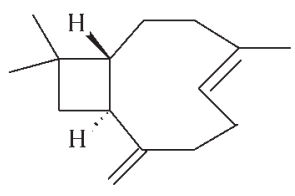

trans $-<\mathrm{f} 128>\mathrm{b}<\mathrm{f} 255>-$ Caryophyllene

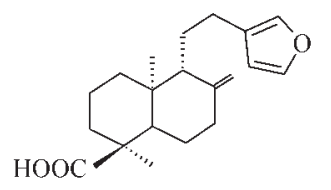

Polyalthic acid

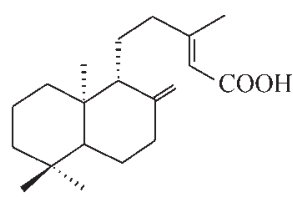

Copalic acid

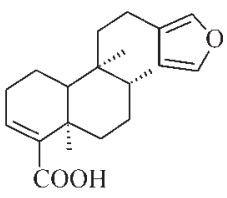

Hardwickiic acid
Figure 1 - Terpenes in the oleoresin of Copaifera duckei Dwyer. 
statistically significant differences in the mean number of micronuclei (MN) in peripheral blood reticulocytes (RETs) of the rats in any of the experimental groups as compared between themselves or with the negative control group (Table 1). At the three concentrations tested, a small but statistically non significant increase was observed between the mean number of micronucleated reticulocytes (MNRETs) after 24, 48 and $72 \mathrm{~h}$ as compared with their respective $0 \mathrm{~h}$ controls. No sex differences were observed between any of the groups.

As compared to rats in the negative control group, the mitotic index (Table 2) of rats in the $10 \% \mathrm{LD}_{50}$ group was not significantly different but rats in the $25 \%$ and $50 \% \mathrm{LD}_{50}$ groups showed a significant decreases $(p<0.05$ and $\mathrm{p}<0.01$ respectively).

There were no statistically significant differences in the mean number of chromosome aberrations between the three experimental groups and the negative control group (Table 2). In all treatments with Copaifera oleoresin the most frequent chromosomal aberrations observed were chromatid breaks, followed by chromatid gaps, deletions and isochromatidic gaps.

\section{Discussion}

The in vivo rat micronuclei test and chromosome aberrations assay are two of the most frequently used and sen- sitive tests for investigating the genotoxic profile of chemicals, these tests having been recommended for routine analysis because they produce results that are considered highly relevant in the human context (Morita et al., 1997; Preston et al., 1987). The Copaifera duckei oleoresin analyzed by us was very rich in diterpene acids and possessed moderate amounts of sesquiterpene hydrocarbons, confirming the report by Cascon and Gilbert (2000) that there are differences in the chemical composition of the oleoresin produced by different Copaifera species.

Terpenes are abundant in superior plants and show a shared structure of isoprene units, the sesquiterpenes $\left(\mathrm{C}_{15}\right.$ $\left.\mathrm{H}_{24}\right)$ having three such units and the diterpenes $\left(\mathrm{C}_{20} \mathrm{H}_{32}\right)$ four (Robbers et al., 1997). Some sesquiterpenes and diterpenes are known to be cytotoxic and to inhibit tumors, with toxic sesquiterpenes generally containing one or more functional alkylating groups which suggests that they are possibly mutagenic and carcinogenic (Cassady and Baird, 1990; Wall et al., 1998).

Our data shows that treatment $C$. duckei oleoresin resulted in depression of mitotic activity and no statistically significant increase in chromosome aberrations in bone marrow cells and in the mean number of MNRETs in the peripheral blood of Wistar rats. The dose related decrease in mitotic index (Table 2) indicates that $C$. duckei

Table 1 - Number of micronucleated reticulocytes (MNRETs) observed in the peripheral blood cells of female $\left(F_{1}\right.$ to $\left.F_{3}\right)$ and male $\left(M_{1}\right.$ to $\left.M_{3}\right)$ Wistar rats treated with Copaifera duckei oleoresin. For each time period $(0,24,48,72 \mathrm{~h}) 2000$ cells were analyzed, giving a total of 8000 cells per animal.

\begin{tabular}{|c|c|c|c|c|c|c|c|c|}
\hline \multirow[t]{2}{*}{ Treatment } & \multirow[t]{2}{*}{ Time (h) } & \multicolumn{6}{|c|}{ Number of MNRETs per Animal } & \multirow{2}{*}{$\begin{array}{l}\text { Mean number of } \\
\text { MNRETs } \pm \text { SE }\end{array}$} \\
\hline & & $\mathrm{F}_{1}$ & $\mathrm{~F}_{2}$ & $\mathrm{~F}_{3}$ & $\mathrm{M}_{1}$ & $\mathrm{M}_{2}$ & $\mathrm{M}_{3}$ & \\
\hline \multirow[t]{4}{*}{$\mathrm{NaCl} 0.9 \%$ (negative control) } & 0 & 4 & 2 & 6 & 2 & 2 & 4 & $3.33 \pm 0.66$ \\
\hline & 24 & 5 & 2 & 3 & 5 & 4 & 4 & $3.83 \pm 0.47$ \\
\hline & 48 & 3 & 1 & 1 & 3 & 3 & 2 & $2.16 \pm 0.40$ \\
\hline & 72 & 2 & 5 & 4 & 5 & 4 & 5 & $4.16 \pm 0.47$ \\
\hline \multirow[t]{4}{*}{ Copaifera oleoresin $10 \%$ of $\mathrm{LD}_{50}$} & 0 & 2 & 1 & 0 & 0 & 0 & 2 & $0.83 \pm 0.40$ \\
\hline & 24 & 1 & 0 & 1 & 2 & 1 & 1 & $1.00 \pm 0.26$ \\
\hline & 48 & 3 & 1 & 2 & 2 & 1 & 2 & $1.83 \pm 0.31$ \\
\hline & 72 & 2 & 1 & 2 & 3 & 2 & 1 & $1.83 \pm 0.31$ \\
\hline \multirow[t]{4}{*}{ Copaifera oleoresin $25 \%$ of $\mathrm{LD}_{50}$} & 0 & 3 & 3 & 2 & 2 & 0 & 0 & $1.66 \pm 0.56$ \\
\hline & 24 & 2 & 5 & 2 & 2 & 3 & 3 & $2.83 \pm 0.48$ \\
\hline & 48 & 2 & 3 & 2 & 8 & 4 & 4 & $3.83 \pm 0.91$ \\
\hline & 72 & 5 & 3 & 4 & 8 & 2 & 4 & $4.33 \pm 0.84$ \\
\hline \multirow[t]{4}{*}{ Copaifera oleoresin $50 \%$ of $\mathrm{LD}_{50}$} & 0 & 2 & 3 & 4 & 1 & 1 & 1 & $2.00 \pm 0.52$ \\
\hline & 24 & 5 & 3 & 2 & 2 & 5 & 4 & $3.50 \pm 0.56$ \\
\hline & 48 & 4 & 3 & 3 & 6 & 4 & 4 & $4.00 \pm 0.45$ \\
\hline & 72 & 3 & 3 & 3 & 9 & 9 & 3 & $5.00 \pm 1.26$ \\
\hline \multirow[t]{4}{*}{ Cyclophosphamide (positive control) } & 0 & 4 & 5 & 6 & 2 & 6 & 2 & $4.17 \pm 0.75$ \\
\hline & 24 & 11 & 11 & 10 & 12 & 16 & 10 & $11.6^{*} \pm 0.92$ \\
\hline & 48 & 12 & 12 & 10 & 10 & 26 & 17 & $14.5^{*} \pm 2.53$ \\
\hline & 72 & 14 & 12 & 11 & 10 & 16 & 12 & $12.5^{*} \pm 0.88$ \\
\hline
\end{tabular}

*Significantly different from negative control and all other treatments at $\mathrm{p}<0.001$.

$\mathrm{SE}=$ standard error. 
Table 2 - Mitotic Index and distribution of the different types of chromosomal aberrations $(\mathrm{CA})$ observed in bone marrow cells of female $\left(\mathrm{F}_{1}\right.$ to $\left.\mathrm{F}_{3}\right)$ and male $\left(\mathrm{M}_{1}\right.$ to $\left.\mathrm{M}_{3}\right)$ Wistar rats treated with a Copaifera duckei oleoresin. For each treatment 100 cells per animal were analyzed, giving a total of $\mathrm{n}=600$ cells per treatment.

\begin{tabular}{|c|c|c|c|c|c|c|c|c|}
\hline \multirow{3}{*}{ Treatments } & \multirow{3}{*}{ Sex } & \multirow{3}{*}{$\begin{array}{c}\text { Mitotic } \\
\text { index (\%) }\end{array}$} & \multicolumn{5}{|c|}{ Chromosomal aberrations } & \multirow{3}{*}{$\begin{array}{c}\text { Total (CA) } \\
\text { without gaps }\end{array}$} \\
\hline & & & \multicolumn{2}{|c|}{ Gaps } & \multicolumn{2}{|c|}{ Breaks } & \multirow{2}{*}{$\begin{array}{c}\text { Other aberrations } \\
\text { OA }\end{array}$} & \\
\hline & & & $\mathrm{C}$ & IC & $\mathrm{C}$ & IC & & \\
\hline \multirow{7}{*}{$\begin{array}{l}\mathrm{NaCl} 0.9 \% \\
\text { (negative control) }\end{array}$} & $\mathrm{F}_{1}$ & 7.2 & 0 & 0 & 1 & 0 & 0 & 1 \\
\hline & $\mathrm{F}_{2}$ & 5.8 & 1 & 0 & 0 & 0 & $1 \mathrm{del}$ & 1 \\
\hline & $\mathrm{F}_{3}$ & 4.9 & 2 & 0 & 0 & 0 & 0 & 0 \\
\hline & $\mathrm{M}_{1}$ & 5.6 & 0 & 0 & 2 & 0 & 0 & 2 \\
\hline & $\mathrm{M}_{2}$ & 4.5 & 0 & 0 & 0 & 0 & 0 & 0 \\
\hline & $\mathrm{M}_{3}$ & 8.6 & 0 & 0 & 1 & 0 & 0 & 1 \\
\hline & mean $\pm \mathrm{SE}$ & $6.1 \pm 0.63$ & & & & & & $0.83 \pm 0.31$ \\
\hline \multirow{7}{*}{$\begin{array}{l}\text { Copaifera oleoresin } \\
10 \% \text { of the } \mathrm{LD}_{50}\end{array}$} & $\mathrm{~F}_{1}$ & 4.7 & 0 & 0 & 2 & 0 & 0 & 2 \\
\hline & $\mathrm{F}_{2}$ & 5.3 & 0 & 0 & 0 & 0 & 0 & 0 \\
\hline & $\mathrm{F}_{3}$ & 4.1 & 0 & 0 & 1 & 0 & 0 & 1 \\
\hline & $\mathrm{M}_{1}$ & 6.9 & 0 & 0 & 1 & 0 & 0 & 1 \\
\hline & $\mathrm{M}_{2}$ & 6.6 & 0 & 0 & 1 & 0 & 0 & 1 \\
\hline & $\mathrm{M}_{3}$ & 6.6 & 0 & 0 & 1 & 0 & 0 & 1 \\
\hline & mean $\pm \mathrm{SE}$ & $5.7 \pm 0.47$ & & & & & & $1.00 \pm 0.26$ \\
\hline \multirow{7}{*}{$\begin{array}{l}\text { Copaifera oleoresin } \\
25 \% \text { of the } \mathrm{LD}_{50}\end{array}$} & $\mathrm{~F}_{1}$ & 5.0 & 0 & 0 & 0 & 0 & 0 & 0 \\
\hline & $\mathrm{F}_{2}$ & 5.0 & 0 & 0 & 0 & 0 & $2 \mathrm{del}$ & 2 \\
\hline & $\mathrm{F}_{3}$ & 4.5 & 0 & 0 & 0 & 0 & 0 & 0 \\
\hline & $\mathrm{M}_{1}$ & 4.4 & 0 & 0 & 0 & 0 & 0 & 0 \\
\hline & $\mathrm{M}_{2}$ & 4.1 & 0 & 0 & 1 & 0 & 0 & 1 \\
\hline & $\mathrm{M}_{3}$ & 3.6 & 1 & 0 & 0 & 0 & $1 \mathrm{del}$ & 1 \\
\hline & mean $\pm \mathrm{SE}$ & $4.4 * \pm 0.22$ & & & & & & $0.67 \pm 0.33$ \\
\hline \multirow{7}{*}{$\begin{array}{l}\text { Copaifera oleoresin } \\
50 \% \text { of the } \mathrm{LD}_{50}\end{array}$} & $\mathrm{~F}_{1}$ & 3.3 & 3 & 0 & 2 & 0 & 0 & 2 \\
\hline & $\mathrm{F}_{2}$ & 4.4 & 0 & 0 & 1 & 0 & 0 & 1 \\
\hline & $\mathrm{F}_{3}$ & 3.1 & 2 & 2 & 0 & 0 & $2 \mathrm{del}$ & 2 \\
\hline & $\mathrm{M}_{1}$ & 3.7 & 2 & 2 & 0 & 0 & $3 \mathrm{del}$ & 3 \\
\hline & $\mathrm{M}_{2}$ & 3.2 & 2 & 0 & 1 & 1 & 0 & 2 \\
\hline & $\mathrm{M}_{3}$ & 4.2 & 3 & 0 & 0 & 0 & $2 \mathrm{del}$ & 2 \\
\hline & mean $\pm \mathrm{SE}$ & $3.6^{* *} \pm 0.22$ & & & & & & $2.00 * \pm 0.26$ \\
\hline \multirow{7}{*}{$\begin{array}{l}\text { Cyclophosphamide } \\
\text { (positive control) }\end{array}$} & $\mathrm{F}_{1}$ & 1.9 & 1 & 0 & 2 & 0 & 2 del & 4 \\
\hline & $\mathrm{F}_{2}$ & 1.6 & 1 & 1 & 6 & 0 & $1 \mathrm{del} / 1 \mathrm{dic}$ & 8 \\
\hline & $\mathrm{F}_{3}$ & 2.1 & 1 & 0 & 1 & 0 & $3 \mathrm{del}$ & 4 \\
\hline & $\mathrm{M}_{1}$ & 2.8 & 0 & 0 & 4 & 0 & $1 \mathrm{del}$ & 5 \\
\hline & $\mathrm{M}_{2}$ & 2.6 & 3 & 2 & 6 & 0 & $2 \mathrm{del}$ & 8 \\
\hline & $\mathrm{M}_{3}$ & 2.4 & 3 & 3 & 2 & 1 & $2 \mathrm{del}$ & 5 \\
\hline & mean $\pm \mathrm{SE}$ & $2.2^{* * *} \pm 0.18$ & & & & & & $5.67 * * * \pm 0.76$ \\
\hline
\end{tabular}

Key: $\mathrm{C}=$ Chromatid; $\mathrm{IC}=$ isochromatid; $\mathrm{OA}=$ other aberrations; del $=$ deletion, dic $=$ dicentric; $\mathrm{SE}=$ standard error.

*: Significantly different from the negative control at $\mathrm{p}<0.05$.

$* *$ : Significantly different from the negative control at $\mathrm{p}<0.01$.

$* * *$ : Significantly different from the negative control at $\mathrm{p}<0.001$.

oleoresin depresses mitosis at high doses. Although not statistically significant, the dose related increase in the mean number of MNRETs observed at the two higher doses probably occurred due to cumulative effects of the resin because the rats were treated during three consecutive days.
Sena and Chen (1998) used the micronucleated cell assay and Swiss albino mice to evaluated the in vivo bone marrow cell mutagenic potential of 25,50 and $80 \%$ of the $\mathrm{LD}_{50}$ dose of orally administered Copaifera langsdorfii oleoresin and demonstrated a statistically significant increase micronucleated cells (and hence mutagenic action) 
only at high doses, although these authors used a higher maximum dose than we did.

Donaldson et al. (1994) extensively investigated the cytotoxicity of the antimitotic antitumor diterpene taxol derived from the yew tree Taxus brevifolia and showed that the antimitotic effect of taxol classified it as an important anticancer agent. A genotoxicity study by Dias et al. (1997) showed that taxol had no radio-sensitizing effect on chromosomal aberrations induced by gamma radiation and also did not increase doxorubicin-induced chromosomal aberrations in in vitro Chinese hamster ovary cells.

The active component of Eremanthus elaeagnus wood oil is the sesquiterpene eremanthine, genotoxic evaluation in vivo in rodents and in vitro in human lymphocytes having showed that low concentrations of eremanthine produced no cytotoxic or clastogenic effects and that only doses of $400 \mathrm{mg} \mathrm{Kg}^{-1}$ showed toxicity (Dias et al., 1995). Another sesquiterpene, Glaucolide B, isolated from Vernonia eremophila produced no significant increase in the frequency of chromosomal aberrations in mouse bone marrow cells but showed cytotoxic and clastogenic effects on human lymphocytes in vitro, indicating that caution is needed in its medicinal use (Burim et al., 1999).

Available information about the evaluation of the mutagenic potential of copaiba oleoresin in different rodent species has shown that despite some qualitative differences between the Copaifera oleoresins studied the toxic pattern was similar, with cytotoxic and some genotoxic effects only occurring at high doses. Since there are about 20 different Copaifera species in Brazil and the oleoresins obtained from these plants have been used in popular medicine, it is important to establish the relationship between chemical composition and biological activity of authentic samples of the oleoresins in order to permit their validation as safe and effective phyto-medicines and to allow adequate quality control.

The results of our study demonstrate that under the experimental conditions employed Copaifera duckei oleoresin presented cytotoxic effects at high doses but did not induce a statistically significant increase in the mean number of chromosome aberrations in the bone marrow cells or in the mean number of MNRETs from the peripheral blood of Wistar rats in vivo.

\section{Acknowledgments}

This investigation was supported by UNIFENAS, UFRJ and FAPEMIG (Rede Mineira de Ensaios Toxicológicos e Farmacológicos de Produtos Terapêuticos, EDT 1879/02). We are grateful to Jonas de Oliveira Cardoso for help in collecting the plant material and to Antônio Sérgio Lima da Silva for botanical identification.

\section{References}

Araújo MCP, Dias FL, Kronka SN and Takahashi CS (1999) Effects of turmeric and its active principle, curcumin, on bleomycin-induced chromosome aberrations in Chinese hamster ovary cells. Genet Mol Biol 22:407-413.

Basile AC, Sertie JA, Freitas PCD and Zanini AC (1988) Antiinflammatory activity of oleoresin from Brazilian Copaifera. Journal of Ethnopharmacology 22:101-109.

Braga WF (1994) Caracterização química dos constituintes do óleo extraído de Copaifera cearensis. M. Sc. Thesis. Universidade Federal do Rio de Janeiro, Rio de Janeiro.

Burim RV, Canalle R, Lopes JLC and Takahashi CS (1999) Genotoxic action of the sesquiterpene lactone glaucolide B on mammalian cells in vitro and in vivo. Genet Mol Biol 22:401-406.

Carvalho JCT and Cascon V (2003) Fitoterápicos: Nova Opção Terapêutica de Antiinflamatórios (Aspectos Químicos, Farmacológicos e Aplicações Terapêuticas). Editora Robe, São Paulo, 630 pp.

Cascon V and Gilbert B (2000) Characterization of the chemical composition of oleoresins of Copaifera guianensis Desf., Copaifera duckei Dwyer and Copaifera multijuga Hayne. Phytochemistry 55:773-778.

Cascon V, Fernandez-Ferreira E, Soares ROA, Gibaldi D, Gilbert B and Ribeiro-Santos R (1998) Avaliação da composição química e da atividade tripanosomicida in vitro de óleo-resinas de Copaifera spp. Resumos do XV Simpósio de Plantas Medicinais do Brasil, Águas de Lindoia, SP, pp 199

Cascon V, Gilbert B, Araújo GL, Rocha LM, Teixeira LA and Carvalho ES (2000) Avaliação da atividade antimicrobiana de óleo-resinas de Copaifera spp. Resumos do XVI Simpósio de Plantas Medicinais do Brasil, Recife, PE, pp 223.

Cassady JM and Baird WM (1990) Natural products as a source of potential cancer chemotherapeutic and chemopreventive agents. J Nat Prod 53:23-41.

Chacon DR, Libera AND, Cintra DEC, Carvalho JCT, Oliveira GA and Maistro EL (2002) Absence of genotoxic and antigenotoxic effects of a standardized extract of the medicinal plant Solanum melongena on peripheral blood and bone marrow cells of Wistar rats. Cytologia 67:417-422.

Dias FL, Takahashi CS, Sakamoto-Hojo ET, Vichnewski W and Sarti SJ (1995) Genotoxicity of the natural cercaricides "Sucupira" oil and Eremanthine in mammalian cells in vitro and in vivo. Environ Mol Mutagen 26:338-344.

Dias FL, Antunes LMG and Takahashi CS (1997) Effect of taxol on chromosome aberrations induced by gamma radiation or by doxorubicin in Chinese hamster ovary cells. Braz J Gen 20:389-395.

Donaldson KL, Goolsby GL and Wahl AF (1994) Cytotoxicity of the anticancer agents cisplatin and taxol during cell proliferation and the cell cycle. Int J Cancer 57:847-855.

Dwyer JD (1951) The Central American, West Indian and South American species of Copaifera (Caesalpinaceae). Brittonia 7:143-172.

Fernandes RM and Pereira NA (1989) Copalic acid analgesic activity in mice. Abstracts do Simpósio Brasil-China de Química e Farmacologia de Produtos Naturais, Rio de Janeiro, pp 248.

Fernandes RM, Pereira NA and Paulo LG (1992) Anti-inflammatory activity of copaiba balsam (Copaifera cearensis Huber). Rev Bras Farmácia 73:53-56. 
Gilbert B, Mors WB, Baker PM, Tomassini TCB, Goulart EG, Holanda JC, Costa JAR, Lopes JNG, Santos-Filho D, Sarti SJ, Turco AM, Vichnewski W, Lopes JLC, Thames AW, Pellegrino J and Katz N (1972) A atividade anti-helmíntica de óleos essenciais e de seus componentes químicos. Anais da Academia Brasileira de Ciências 44(supl.):423-428.

Ford CE and Hamerton JL (1956) A colchicine, hypotonic citrate, squash sequence for mammalian chromosomes. Stain Technol 31:247-251.

Hayashi M, Morita T, Kodama Y, Sofuni T and Ishidate Jr M (1990) The micronucleus assay with mouse peripheral blood reticulocytes using acridine orange-coated slides. Mutat Res 245:245-249.

Le Cointe P (1934) Árvores e Plantas Úteis: A Amazônia Brasileira (III). Livraria Clássica, Belém, 486 pp.

Lima SEM, Cascon V and Pereira NA (1998) Estudo dos efeitos da óleo-resina de copaíba sobre células de melanoma B16F10 em camundongos C57BL/6J. XIII Reunião Anual da Federação de Sociedades de Biologia Experimental (FESBE), Caxambu, pp 391-392.

Maruzzella JC and Sicurella NA (1960) Antibacterial activity of essential oil vapors. J Amer Pharmac Assoc 49:692-694.

Morita T, Asano N, Awogi T, Sasaki YF, Sato S, Shimada H, Sutou S, Suzuli T, Wakata A, Sofuni T and Hayashi M (1997) Evaluation of the rodent micronucleus assay in the screening of IARC carcinogens (Group 1. 2A and 2B). The summary report of the $6^{\text {th }}$ collaborative study by CSGMT/JEMS MMS. Mutat Res 389:3-122.

Ohsaki A, Yan LT, Shigeru I, Edatsugi H, Iwata D and Komoda Y (1994) The isolation and in vivo potent antitumor activity of clerodane diterpenoid from the oleoresin of the Brazilian medicinal plant, Copaifera langsdorfii Desfon. Bioorg Med Chem Lett 4:2889-2892.

Opdyke DLJ (1976) Balsam copaiba. Food Cosmet Toxicol 14:687.
Paiva LAF, Rao VSN, Gramosa NV and Silveira ER (1998) Gastroprotective effect of Copaifera langsdorffii oleoresin on experimental gastric ulcer models in rats. J Ethnopharmac 62:73-78.

Pellegrino J (1967) Protection against human Schistosome cercariae. J Exper Parasitol 21:12.

Pio-Corrêa M (1984) Dicionário das Plantas Úteis do Brasil, e das Exóticas Cultivadas. Imprensa Nacional, Rio de Janeiro, v. I, pp 86-87; v. II, pp 370-375.

Panigrahi GB and Rao AR (1982) Chromosome-breaking ability of arecoline, a major betel-nut alkaloid, in mouse bonemarrow cells in vivo. Mutat Res 103:197-204.

Preston RJ, Dean BD, Gallow S, Holden HE, Macfee AF and Shelby M (1987) Mammalian in vivo cytogenetic assay analysis of chromosomal aberration in bone marrow cells. Mutat Res 189:157-165.

Robbers JE, Speedie MK and Tyler VE (1997) Farmacognosia e Farmacobiotecnologia. Editorial Premier, São Paulo, 372 pp.

Sena MA and Chen LC (1998) Avaliação da mutagenicidade do óleo de Copaíba (Copaifera langsdorfii Desfon) em eritrócitos da medula óssea de camundongos. Genet Mol Biol 21(suppl):E.65.

Tincusi BM, Jiménez IA, Bazzocchi IL, Moujir LM, Mamami ZA, Barroso JP, Ravelo AG and Hernández BV (2002) Antimicrobial terpenoids from the oleoresin of the Peruvian medicinal plant Copaifera paupera. Planta Medica 68:808812.

Veiga-Junior VR, Zunino L, Calixto LB, Patituti ML and Pinto AC (2001) Phytochemical and antiedematogenic studies of commercial copaiba oils available in Brazil. Phytot Res $15: 476-480$.

Savage JRK (1976) Classification and relationships of induced chromosomal structural changes. J Med Genet 13:103-122.

Wall ME, Wani MC, Hughes TJ and Taylor H (1988) Plant antimutagenic agents. 1. General bioassay and isolation procedures. J Nat Prod 51:866-873.

Associate Editor: Catarina S. Takahashi 